District No. 5 comprises the parish of Powick. Salary, $£ 20$ per annum.

Midwifery eases, when attended under an order from the proper authorities, $10 \mathrm{~s}$. $6 \mathrm{~d}$. each. Successful cases of vaccination, $1 s .6 d$. each; with such extra sums for fractures, dislocations, \&c. \&c., as are specified in the last order of the poor-law board.

The duties of the medical officers will extend to affording medical relief and surgical assistance, medicines, leeches, and appliances, (except trusses, to all such paupers falling ill within their respective districts, as the board of guardians or other duly authorized persons may direct to receive the same. By order of the Board,

Board-room, Upton-on Severn,

J. SKEY. July 20 th, 1818,

\section{INQUIRY AT THE FEVER HOSPITAL, LIVERPOOL.} To the Editor of THE LANCET.

Sir,-The leading article of The LANCET of Saturday last contains a paragraph referring to a recent inquiry here, and alluding to certain members of the committee in a manner which is deemed offensive; and as my name is also mentioned I request yon will, by publishing this letter in your next number, afford me the opportunity of disclaiming all knowledge of, or connexion with, directly or indirectly, the party or parties who furnished you with the information, which, I may add, is incorrect, for one of the gentlemen evidently alluded to had no connexion whatever with the inquiry.

As regards my own position in the matter, $I$ am in the hands of the poor-law board, who will cause a full and impartial inquiry to be instituted, and I am therefore sure of obtaining justice.-I am, Sir, your obedient servant, Fever Hospital, Liverpool, July 26 th, 1848.

A. B. STEELE.

\section{THE LATE INQUEST AT PORTSMOUTH.} To the Editor of The LaNCET.

Srn,-In my last communication I inadvertently made an error in saying, "The conjugate axis measured five in place of four inches. Will you have the kindness to rectify this in your errata, thus : For "five" read "four" inches.

Portsmouth, Jnly, 1848 . I remain, Sir, yours truly,

SIR,- On reading the account of the very extraordinary case reported in the last number of your valuable journal-viz., the inquest on the body of a Mrs. Webster, who died at Southsea during an attempt to induce premature labour,-I could not but lament that a more satisfactory account of it had not been furnished by some of the parties more immediately coneerned. I have no observation to make, in this letter. on the practice of Dr. Stewart. It is with the surgeon's (Mr. Garrington's) testimony, who made the sectio-cadaveris, I purpose now to deal. With singular inconsistency he pronounces the pelvis in this case of nearly its natural dimensions, and yet states that it might have proved an insurmountable obstacle to delivery! Next he declares that neither the uterus nor the vagina were pierced by the instrument used for puncturing; and yet declares the cause of death to have proceeded from a small aperture in the iliac artery, with a similar corresponding aperture or opening in the peritonaum. It seems to me, Sir, to come more within the range of probabilities, that a puncture either in the uterus or vagina might have escaped detection, than that an artery should have burst or opened, and the peritonæum burst or opened at the same time, so as to permit the passage of its current of blood; that artery, too, being in the pelvic cavity, so immediately contiguous to the part meant to be punctured; and that, also, at the very precise moment when a stilette was introduced into the uterus, for the purpose of piercing the investing foetal membrane. Mr. Garrington will surely think it right to afford some further explanation of this most extraordinary circumstance, and still more extraordinary coinci. dence.

Portsea, July, 1848.

J. P.

\section{TREATMENT OF NAVAL ASSISTANT-SURGEONS.}

\section{To the Editor of The Lancet.}

SIr,-Although not a member of the medical profession, I am a reader of THE LANCET, and have watched with great pleasure the progress of the agitation on the subject of the treatment of assistant-surgeons in the naval service. Five years' constant service afloat, as midshipman, gave me an opportunity of becoming familiar with their position, and per. haps may entitle me to pronounce an opinion on the subject. Now, Sir, let me say, first, that to call these gentlemen "useful members of the profession," is only to state one-third of their merits. They are a body of estimable and accom. plished men; in fact, in very many instances, almost the only persons in a ship, in whose conversation an intellectual or literary person could find anything to instruct or interest him. I still remember with pleasure the apt quotation, the felicitous remark, and the agreeable anecdote, which cheered and re freshed me, from the lips of a medical messmate; and which was doubly welcome, after the noise, the babble, and the obscenity of the "conversation" of a berth. Let me add, that these gentlemen are most attentive to their duties, and kind and considerate in the performance of them. For this reason they are generally popular among the men, to whom it is of course gratifying to meet with gentleness in the sick-bay, after ruffianism on the upper-deck, from other quarters.

Yet how are these gentlemen treated, in the vessels of which they are the ornaments? Not only have they nocabins, not only are they compelled to live among a mob of young men, whose education has finished at fourteen years of age, but, in very many instances, they are actually exposed to personal insult and annoyance from the cubs around them, who ought to be proud of their society. I speak what is a well-known fact, when I say that a newly-joined assistant-surgeon is generally submitted to a course of what cockneys call "chaff" petty personalities, equally vulgar, heartless, and dull. The late Mr. Douglas, surgeon R.N., in whose brilliant writings one is reminded of the best parts of Bulwer, and the vigour of Warren, was treated in this way on joining the service first. Fancy the effect of such conduct on the mind of such a man! I had never the pleasure of seeing him, but I recol. lect hearing an account of the whole affair, my informant adding, that Douglas had threatened in the mess to write to the Times on the subject. Perhaps it would have been as well if he had done so, and so hastened the result of the pre. sent agitation, which must end in triumph, being founded in reason, and only opposed by stupidity.

In the Snake, 16 guns, in which $\mathbf{I}$ served from October 1842 , to October, 1843 , there were eight of us, in a little berth destitute of air and light; the assistant-surgeon was exposed to every inconvenience, and had only at his command a dirty little hole called a "dispensary," and worse situated than the cabins of the boatswain, gunner, and carpenter. No gentle. man would keep a terrier in such a place as the Admiralty had bestowed upon, and thought good enough for, a scholar and a gentleman. I was subsequently in a corvette, of a superior nature to the brig Snake. The assistant-surgeon who served in her at that time has since left the profession-I presume, in disgust and disdain-and $I$ am not surprised at it. I seems astonishing to me, that such a state of things should exist for an instant, or any one be found to open his mouth in defence of a system, the immediate effect of which is to puta scientific man serving his country in a position where he cannot read or write. That is the plain fact; and the Admiralty should remember, that though they can do well enough without reading, (as would appear from their conduct, intellectual men cannot, and will not.

I have not the sinallest personal or private interest in the matter, and I speak simply as a friend of an estimable and ill used class, and purely on public grounds. I think it the duty of every man to contribute his mite to a good cause, and can see no reason why a lieutenant should have a cabin to snooze in, and an assistant-surgeon none, for the purposes of study. London, June, 1848 . I am, Sir, your obedient servant,

\section{QUACKERY.-DEATH AFTER TAKING COCKLE'S PILLS.}

To the Editor of THE LANCET.

DeAR Str,-The enclosed is another example of the dreadful effects of quack pills, \&c. The unfortunate man has left a widow and fourteen children, who were dependent on him. He was a farmer in middling circumstances.-Yours truly,

Heckington, July, 1848. A Subscriber OF TWENTY-FIVE YEARS

Medical Certificate of (ABSTRACT.)

of the Cause of Death.-Name, Thomas Crears last birthday. Was attended by me, and died on the 10th day of July, 1848. Cause of death: Cockle's pills, producing excessive diarrhoa, irrita bility of the stomach and bowels, spasm, exhaustion. Duration of disease, six days. (Signed)

Wirliam GrbBs, M.R.C.S. \& L.A.C 